OPEN ACCESS

Edited by:

Liz Thomas,

Edge Hill University, United Kingdom

Reviewed by:

Jo Redcliffe,

Swansea University, United Kingdom Stacey Louise Mottershaw, University of Leeds, United Kingdom

*Correspondence:

Catherine Mann cvmann@unimelb.edu.au

Specialty section:

This article was submitted to Leadership in Education, a section of the journal Frontiers in Education

Received: 31 January 2020 Accepted: 03 June 2020

Published: 09 July 2020

Citation:

Mann C (2020) Advising by Design: Co-creating Advising Services With

Students for Their Success.

Front. Educ. 5:99.

doi: 10.3389/feduc.2020.00099

\section{Advising by Design: Co-creating Advising Services With Students for Their Success}

\author{
Catherine Mann* \\ Student Success, The University of Melbourne, Melbourne, VIC, Australia
}

With global trends turning toward increased personalization and expectations of higher education, the question of how to design relevant and high-quality advising services at scale that support learning outcomes, improve the student experience, and enhance the acquisition of employability skills is a central challenge for many universities. The emergence of co-creation principles to better shape relevant solutions to engage students can also be applied to advising practice. This article explores the role of design thinking applied to advising at both the strategic and operational levels within one Australian university. With a holistic methodology, design thinking considers the needs of everyone in the system, delivering qualitative data that provides insights into behaviors and drivers that have implications for the ways in which advising services are defined, designed, and delivered. It suggests that advising practice and the process of Human Centered Design share methods that can be powerful in bridging the gap that many students perceive between the institutional offering and the student experience.

Keywords: academic advising, co-creation, design thinking, student services, student success

\section{INTRODUCTION}

Advising students on curricular and co-curricular choices that support student success is increasingly recognized by educational policy makers as an integral component in enabling confident, capable, and critically-thinking learners who are ready for the world of work (Campbell and Nutt, 2008, p. 5; Kift et al., 2010, pp. 7-8; Young-Jones et al., 2013, p. 9). Yet engaging students in quality advising continues to be a shared challenge for higher education institutions across the globe. With many students struggling to connect within their disciplines, there is an even greater challenge to help them find connections outside the curriculum in ways that are increasingly personalized and individualized, whether it be with academic and professional staff, or their fellow students (Baik et al., 2019, pp. 683-684). Students are at the heart of what we do yet are often removed from the solutions we provide, sometimes resulting in a mismatch between expectations on both sides and a disjunction between support and experience, particularly for international students (Roberts and Dunworth, 2012, pp. 525-526) and students who require support to prevent early departure (Coates, 2014, p. 21). While universities recognize the importance of the student experience as a concept, how do we personalize it, apply it and scale it in the design of curriculum and services?

The emergence of co-creation principles to better shape relevant solutions to engage students can also be applied to advising theory and practice. Advising from student insights can be institutionally powerful in bridging the gap that many students perceive between the institutional offering and the student experience. This paper will examine some ways in which students create 
and influence the design of advising programs at one university in Australia. It suggests that the idea of employing a range of defined methodologies drawn from design thinking can bring new insights into how institutions address advising impact and new ways of partnering for student success. In doing so, it contributes to the growing body of literature on academic advising and personal tutoring, and the integral role this function plays in the student experience, student learning and engagement, and student success by increasing the understanding, empathy, and value of students' lived experiences and their view on what assists and supports them to succeed. In doing so, it draws parallels between individual advising practice and the application of Human Centered Design (HCD) principles in designing advising activities and interactions with students.

\section{THE STUDENT EXPERIENCE}

The "student experience" has been gaining ground at the forefront of higher education learning, teaching, and engagement strategies over the past two decades. With widening participation, the globalization of education, changes in learning and teaching practices, increased opportunities outside higher education, and students' multiple commitments, the totality of students' experience is under review, requiring universities to be more expansive in how they enable and negotiate student engagement both in and out of the classroom (McInnis, 2003, pp. 12-16). The student experience includes not just academic learning and engagement, but the non-academic experience as well as a range of cognitive, social, and emotional dimensions that contribute to student success (De Silva and Garnaut, 2011, p. 72; Picton et al., 2018, p. 1262). As well as encapsulating the whole person, a whole-of-institution, embedded and coordinated, or "third generation" approach to student success and retention is now considered essential, particularly in supporting the first year experience (Kift and Nelson, 2005, p. 226; Kift et al., 2010, p. 10; Nelson et al., 2012a,b, pp. 186-187; Kift, 2015, pp. 58-59) and a "whole-of-student-experience" approach for those students who are at risk of attrition or poor academic performance (Cox and Naylor, 2018). The Student Experience Survey administered by the Social Research Center is now a key tool in the measurement of quality indicators for learning and teaching in higher education in Australia at the national level. It is used to assess and rank institutions according to how students rate a range of aspects of their experience including their perceptions of the quality of teaching, their sense of belonging, learning resources, student support, and academic and employability skills (QILT, 2019, pp. 80-84). With the Australian student experience falling behind that of the US and UK (QILT, 2019, p. vi), tackling it requires a whole-of-institution approach with staff working across disciplinary and service boundaries to achieve measurable and improved outcomes for students.

\section{Education and Advising in Australia}

This is significant in the Australian advising context. As the student experience becomes more multi-faceted, there is an increasing need for advisers to be interlocutors between the rules, regulations, and requirements of the university and the individual personal, educational, and career goals students bring, develop, and change along their student journey. Students in the Australian higher education context generally choose a major from the beginning of their 3-year undergraduate degree, similarly to the UK. There is some flexibility in their selection of elective subjects, but the study tends to be focused on specific disciplines in contrast to the broader subject choice offered in the first 2 years of the US system. Most Australian universities offer professional degrees at the undergraduate level, meaning that many students will enter directly into areas like Medicine, Law, Engineering, and Teaching. The University of Melbourne reconfigured its curriculum in 2008 to broaden the base of its undergraduate degrees and introduce professional qualifications at the graduate level, providing a structure that US students may find more familiar. However, while more students may be exploratory at the beginning of their degree, the focus on the major requires many of them to specialize early, and many arrive with a clear goal in mind. In general, students are not assigned to an academic adviser or personal tutor to assist them in exploration of their course and career pathways. For most universities in Australia, there is no defined "academic adviser," although Melbourne has just introduced this role as part of a move toward creating better connections between undergraduate students and academic staff. Students are therefore required to be highly independent in their course and subject selection, proactively seeking assistance when needed. Without the personal tutor or academic adviser of the northern hemisphere contexts to anchor the student throughout their entire journey and remain a point of constant connection, students may need to navigate the profusion of rules, courses, subjects, and curriculum themselves or with the guidance and advice of a range of staff.

Compared to the long-standing advocacy for academic advising as teaching and learning advocated for by NACADA in the US (Drake, 2013, pp. 17-26; Wilcox, 2016), or the historical structures of personal tutoring offering a pathway for holistic, personalized support that is emergent in the UK (Lochtie et al., 2018, pp. 2-3), "academic advising" as a function is largely undefined in Australian higher education. Terms differ across institutions making it challenging to gain insights into different roles and responsibilities. "Academic" or "student" advice is provided by a range of academic and professional staff in different roles either formal or informal. With only one quarter of universities using academic staff in their formal advising models, much advising on curricular and co-curricular choices rests with professional staff, often in student services, and increasingly accessed through centralized service centers ${ }^{1}$. Specialist advice such as that offered by Academic Skills or Careers Services is still additional rather than embedded in nature, although several institutions-including Melbourne-are moving in this direction. Advisers working with special populations such as first year students, First in Family, students identifying as LGBTIQ, equity cohorts, students with a disability, Indigenous

\footnotetext{
${ }^{1}$ A 2019 desktop review of 41 universities in Australia revealed 17 have centralized student support, 12 decentralized, 4 have a shared service model, 1 has embedded advice, and 6 did not mention their support or advising structures. Unpublished.
} 
and First Nations students, elite athletes, international students, and overseas students (largely on exchange), all provide critical support to students throughout their time at university. But students may only see an adviser once and have no single person assigned to them for the duration of their course who gets to know them across time or who can help them build a plan for the future that can be revisited and rethought as their own development and learning progresses. Partnership, then, between academic and professional staff in different advising roles is crucial to ensuring that the student experience is considered holistically and remains connected to the academic mission of the university, particularly for the foundational first year experience (Kift et al., 2010, p. 8).

Partnership between staff and students is another critical nexus increasingly influencing the student experience. The concept of elevating student participation to partnering or cocreating with students, of bringing their voices into the design of curriculum and support services, has been a developing body of literature over the past decade. Several studies have explored how to engage students as partners in the design of curriculum (Carey, 2013, p. 258) and interrogated the nature, level and reciprocity of their participation in projects with academic staff (Bovill, 2017, p. 2). Student voice has also been recognized in the design and delivery of student support services and its role in co-creating conditions for student success (Allen and Nichols, 2017, p. 126). Co-creation and the student voice can also be applied to the broader operational environment of the university (Varnham, 2018, p. 7) along with its wide applicability at different levels of the institution, including responding to strategic and operational imperatives (Bovill et al., 2016, p. 197). One way of ensuring that advising is conceptualized and delivered holistically in partnership with students is to involve students alongside staff in the co-design, co-development, and even co-delivery of advising interactions, experiences, and services.

\section{DESIGN THINKING}

An effective method for bringing student and staff voices together into institutional conversations, curriculum, and collaborations is through design thinking. This set of methods, thinking, and practice places people at the heart of decision making by using an empathy-based, creative, user-centered process of problem-solving (Goldman and Kabayadondo, 2017, p. 4; Karpen et al., 2017, pp. 390-391). Focused on seeking solutions through collaborative, experiential, and kinesthetic learning theories, it has its roots in practical, process-based problemsolving in manufacturing and engineering. Evolving into an embedded methodological approach to professional design, it has become an influencer in educational theory and practice in a range of settings through the primary, secondary, and tertiary sectors (British Design Council, 2007, pp. 6-8; Davis and Littlejohn, 2017, p. 24; Goldman and Kabayadondo, 2017, pp. 4-6). More recently, design thinking has extended into the business, marketing, and management disciplines, with design-based methods and tools being applied in a range of customer experience and organizational settings through the lens of service design (Karpen et al., 2017, p. 393; Stickdorn et al., 2018, p. 22). The links between business and education to provoke creative, lateral and human-focused solutions to "sticky" problems is being lead especially in the US through the Stanford Design School and the influential IDEO studio, and in the UK with the British Design Council, encouraging design-based thinking in multidisciplinary centers of excellence in universities to harness creativity, science, and technology in the interests of economic growth (British Design Council, 2010, p. 2; Goldman and Kabayadondo, 2017, p. 9; Roth, 2017, p. xvii). A global move toward implementing the benefits and features of design thinking in the teaching and learning context has also had implications for how universities think about and address problems and opportunities related to the student experience more broadly. The process of design thinking and its application to services through service design provides a way to systematically and productively engage students as cocreators in designing, re-designing or improving services and learning experiences that they have defined, tested, and validated as relevant, engaging, and timely. In terms of partnership with students, service design goes beyond traditional student representation and stakeholder consultation methods, to instead provide human-centered solutions for all participants-students, staff, and stakeholders alike.

The concept of design thinking is starting to gain traction in some literature on student engagement, learner support, and student partnership. Arvanitakis and Hornsby's Citizen Scholar model, for example, includes one quadrant on design thinking with a focus on people-centered thinking, aesthetics, and ethical leadership (Arvanitakis and Hornsby, 2016, p. 18). Elisabeth Dunne references design thinking as a quadrant in her Four Modes of Student Engagement to provide a pedagogical focus for students as change agents who build ideas from the ground up (Dunne, 2016, Preface). Drawing on these models, Emily McIntosh has also outlined a range of skills students can acquire through design thinking when engaged in specific active-learning opportunities such as Peer Assisted Study Sessions where they consider the learner experience and welfare of other peers within their group (McIntosh, 2017, pp. 10-11). For faculty and staff engaged in student development and academic advising, the process and method of design thinking as described by Goldman and Kabayadondo is aimed at similar learning outcomes to those exemplified in good academic advising: "To develop mindset changes ... commitment to action-oriented problem-solving, a sense of efficacy, and understanding that failure and persistence ... are necessary and productive aspects of success" (Goldman and Kabayadondo, 2017, p. 3).

\section{ADVISING BY DESIGN}

The University of Melbourne has been using design thinking to co-create a range of services and programs with students through a series of projects touching all stages of the student lifecycle. Using a variety of methods, drawing on a range of tools, and producing a series of artifacts such as student journey maps, personas, stakeholder maps, and service blueprints 
(Karpen et al., 2017, p. 385), the University is adopting a new approach to linking strategic direction with operational excellence by ensuring that the student voice infuses all parts of decision-making that affects students. From delivering new social and community spaces to administrative processes, from the first year experience to careers services, and from students experiencing academic failure to those engaged in leadership, the University has adopted Human-Centered Design (HCD) approaches to learning about student behavior and stakeholder needs, framing the critical question, iterating prototypes, and delivering benefits, or defining, ideating, prototyping, and testing (Goldman and Kabayadondo, 2017, pp. 3-4). The University has particularly adopted the Design Council's Double Diamond method for service design (British Design Council, 2015, p. 6). The first phase, Discover, frames initial questions and encourages empathy through deep listening: activities are designed to elicit uncensored insights into how the group feels and thinks about what they want and need in relation to a core problem. The second, Define, focuses on framing hypotheses and parameters based on the insights of the Discover phase. The third, Develop, provides an opportunity for fast collaboration, testing, ideation, and prototyping with a "no wrong answer" philosophy. The final stage, Deliver, is implementation and feedback: putting the service or product into practice or market, and reflecting and building on lessons learned (British Design Council, 2015, p. 7).

\section{The International Onboarding Experience}

One of the first advising and student support HCD projects the university engaged in was around improving the commencing international student onboarding journey in 2017. Just over $40 \%$ of the total student cohort is international at the University of Melbourne, with students entering each year from a range of countries. This project recognized what other research has demonstrated: that for many international students, their experience is still fragmented, misunderstood, isolated, and disassociated from the experience of domestic students (Burdett and Crossman, 2011, p. 57; Arkoudis et al., 2019, pp. 803, 807). Building on customer journey maps delineated with currently enrolled students who could reflect on their own start at university, the project identified onboarding-a period defined from accepting their offer to arrival-as a key stage in starting life as a university student and sought to understand what types of support students might need to improve and optimize their experience. Initial research into the ways students experienced onboarding led to the identification of four key touchpoints that students valued as key to this process: communications from the university, accommodation, their preparedness for tertiary learning, and their readiness for Melbourne (University of Melbourne, 2017). Each of these revealed a range of individual and shared insights that enabled facilitators to synthesize into core findings. Students described the complexity of communications, a lack of awareness of accommodation options, a heavy reliance on friends and peer channels for information, and wanting to be inspired and engaged in their course and subject selection beyond the administrative function. HCD-based interactive sessions were then run in which students were invited to generate solutions using service design tools such as story-boarding, post-it note ideation and drawing which invoked a range of potential areas for experimentation. Staff were also engaged in a series of discussions and workshops to discover what their experiences of delivering onboarding were which similarly revealed a fragmented, complex and sometimes overwhelming experience in which different staff across services and departments sought to understand the process, who was accountable for it, and how their individual role contributed to the whole.

By giving international students a dedicated space in which to articulate their experiences, the project team were able to build on the suggestions that students identified as critical to their experience: a unified set of communications outlining what was expected of them and when; information on what sort of accommodation there was in Melbourne; earlier access to course advice and especially advice from other students; and ways to prioritize aspects of their experience to feel readier, earlier. In addition, the overwhelming insight that students valued and desired peer advice more than any other and for all aspects of student life was critical. For staff, these student insights provided the opportunity to rethink and refresh an existing first year advising peer-to-peer program to address an acknowledged gap in providing transition programming for international students who arrive onshore very close to the start of semester. The refresh consisted of expanding an on campus peer advising program to a virtual platform so that offshore and interstate students could access it before they arrived on campus. This dedicated small group advising service targeted at these students was communicated through in-person pre-departure briefings in students' own countries so they were aware of it and then through official university communications throughout the onboarding period. International students could access the peer-led, small group, virtual advising service before they left home to learn from the experience of a later-year student, connect to their peers, ask questions about life, learning, and accommodation, and be reassured in their choices around subjects. Seventeen student peer advisers were trained in developmental advising techniques successfully using student personas developed through another HCD project. The service was run both in and out of hours to accommodate different time zones, and used a technology platform that enabled the peer adviser to facilitate up to 4 students in the conversation. Over 500 students took up this service with just under a quarter completing a survey providing feedback demonstrating that they valued the peer advice, felt reassured about coming to a new country and university, and that their questions were answered. The peer advisers also provided valuable feedback and suggestions for improvement, creating another loop for engagement, skills development and a broader understanding of the support available to students. Importantly, this proactive, individual, advising service prepared participating students for starting life, study, and university in Melbourne, enhancing their early transition, making connections with credible, knowledgeable later-year students, and validating the importance of engaging in interventions early to set up good habits and practices in students before classes start (Thomas, 2012, p. 15; Wood et al., 2016, p. 24). This initial investment in an extended activity was relatively simple and quick to do, provided 
further insights from students who both led and participated, and gives a baseline to further explore validity for another targeted cohort.

\section{Supporting Student Performance}

Another HCD project focused on the increasing numbers of students identified as at risk of poor academic progress. There is agreement across the sector and internationally that this is an area for focus, with students at risk of attrition and poor progress a key factor in student success and engagement literature, especially for those students from non-traditional backgrounds or identified equity groups (Coates, 2014, p. 21; Kift, 2015, pp. 51-52). The University has well-established formal processes for identifying and supporting Students At Risk (SAR) and this is one of the areas in which advising plays a key role. The developmental advising team at Melbourne provides holistic, personalized, and strengths-based advice to these students to support and guide them to a return to good standing. The framework and methods used are very like those used in HCD but applied in an individual setting: advisers first discover what the student's story is, using techniques to build empathy and deep understanding; they then ask the student to define the key moments which led to fail a number, or all, of their subjects. A range of options for academic recovery are developed with the student, including an action plan to document these, a priority rating from the student in terms of importance, and a timeframe for implementation. Most importantly, the advisers continue to work with students throughout the semester to understand what strategies students undertook, how they are feeling and doing in their studies and life at university, and discussing the moderation or development of a new plan.

The research project's initial hypothesis was intended to uncover why students found themselves to be at academic risk, the factors that led them to that point, and the possible range of supports they could identify to help them mitigate further failure. Over 80 students, academic staff from eight faculties, and 27 professional staff from centralized support services participated in design-led research. Students were invited to participate from three different groups: those who had failed and attended an advising appointment; those who failed and did not take up support; and students who were academically successful as a counterpoint to understand what made them so, and how they conceptualized and lived this experience of engagement and success. In the first 2 weeks of the project, the Discover phase, project staff observed SAR appointments, going on a "service safari” (British Design Council, 2015, p. 14), to learn what students revealed and identified about themselves and their perceived reasons for failure. In addition, "user shadowing" was implemented to more intimately understand how some students in the project experienced not just the university but how this part of their lives interacted with other parts (British Design Council, 2015, p. 15). As part of agreeing to participate in the project, students signed a consent form clearly outlining that their deidentified data would be used in the improvement of student services. Four students were shadowed in their homes which meant that they generously agreed to allow staff to visit them and show them how they lived and functioned on a daily basis. This non-judgemental step in the Discover phase built empathy and understanding of these students' complex lives and allowed for observational, contextual queries into their experience of university around work, life, activities, responsibilities, and support. For staff in the project, it was a potent reminder that, while our work is focused on students and the university, for students, failing a subject may be just one factor in a much more complicated set of stressors or situations. This holistic and intensely personal view was a critical step and quickly showed that focusing just on the point at which students failed was too narrow. The SAR process in isolation did not reveal the extent of students' experiences of the university, nor did it provide an understanding of the systemic factors that influence a student's experience, needs, or expectations (University of Melbourne, 2018). As a result, the project scope was redefined to ask the question: How do we effectively support student performance? This refreshed approach revealed that their experience is often complex, fragmented, isolating, inconsistent and variously localized in faculties, departments, and services; that help is provided too late, that services are not always trusted; and that there are many students who are simply too overwhelmed and underprepared for the rules, standards, culture, and pressure of the academic environment. Students bear the burden of navigating complex curriculum, different structures, and diverse staff and were coping with transitions across a range of domains, trying to change, and adapt each time they entered a new subject, a new course, and a new year level.

The project elicited some important results for better understanding a range of needs across groups. It revealed not only student ideas for how to engage them better to address issues of academic failure; it also revealed that many students calibrate failure in different ways, for example, getting 70\% instead of $95 \%$, are less emotionally resilient, have increased wellbeing needs across different cohorts, and may not be used to seeking support. These student insights are important in considering how to design end-to-end services that take account of students' individual and cohort needs, at different touchpoints along their journey. The HCD project has enabled the prioritization of a specific advising pilot initiative: an early alert intervention project with a large undergraduate subject in one faculty as a prototype, itself the start of another discovery process. This intervention consisted of a peer-to-peer advising program, using proactive, intrusive advising to reach out to identified students at two critical touchpoints in semester: once students had received feedback on their first assessment (Varney, 2013, pp. 147148) and as they moved toward exam preparation. Later-year students with lived experience and knowledge of the subject content contacted identified students to discuss how they were going, their understanding of the subject, and strategies for improving their academic performance. While this prototype provided statistically significant improvements in those students who received proactive support, the strongest learning from the prototype was that the resourcing was too intensive and unlikely to offer scalability. Selecting, training, and supporting the student peers was the biggest part of the project. Peers themselves reported finding the advising challenging if students did not want to take their advice to improve their engagement with the 
subject or their marks. Multiplying this small prototype in one subject by hundreds of subjects is not viable. The outcomes from this discovery project have contributed to baseline data for the University to invest instead in a multi-pronged university-wide pilot project aimed at supporting student performance which focuses, not on peer-led, intensive and intrusive advising, but on building a sustainable model of advice that is feasible, scalable, and desirable, enabled by technology and using resources in a more effective way. Design thinking as a holistic model that considers the needs of everyone in the system means that the time spent on identifying the problem through developing empathy at the individual level, alongside the observational, contextual enquiry, revealed patterns that enabled a prototype solution to be tailored and tested before large amounts of time and money were invested in strategic projects.

\section{EMBEDDING DESIGN THINKING}

Design thinking is not just being used to examine systemic problems that affect advising or to identify areas for initial investment in new services; it is also being used to redesign at the existing service level. One of the principles of design thinking is its ability to be adopted and adapted by a range of people and teams. Both the British Design Council and Stanford d. school readily provide access to resources to empower people to facilitate their own design thinking workshops. A series of designthinking boot camps initially run by consultants has grown into a dedicated professional Student Experience and Design team at the University, educating, enabling, and empowering staff across a range of strategic and operational areas to start to embed design-thinking in their own processes for change, ensuring that the student voice is a constant: not only redirecting and validating hypotheses, problem definitions, and generating solutions, but acting as a form of "sense checking" on institutional initiatives. This saturation of design thinking practice within the organization builds staff capability to run their own co-creation workshops with students, as well as provides a low-cost, fail fast way to assess desirability, viability, and feasibility.

\section{Designing a Co-curricular Award}

This "train-the-trainer" approach to enabling staff who work directly with students to employ design thinking methods and tools has opened opportunities for rethinking how to engage students across multi-curricular experiences. An important step change toward building the necessary conditions for a comprehensive and coordinated organizational approach to learning experiences is in igniting the intersections between the curriculum and co-curriculum (Kift et al., 2010, p. 8). For advisers who work with students on their co-curricular, citizenship, and employability skills, design thinking has offered a different range of options to try with students around how they would like their co-curricular activities to be recognized and rewarded. Students were invited through their student portal to attend a "Design your own student award" set of workshops. Over 400 students applied with 150 selected to participate from undergraduate/graduate, international/domestic, gender identity groupings, and a range of discipline areas. Four different workshops were run, two with students who had experience of an existing award and two with no experience of recognition programs. The conditions were set using low fidelity tools-brown paper, Sharpies and post-it notes-for students to empathize with each other, define their key objectives, ideate to generate the maximum number of ideas in the shortest amount of time, and build prototypes of their new award within small groups. After collaborating in these activities, students presented to invited staff and other students on their ideal award's rationale, features, and benefits, as well as the support they identified as essential to successfully completing it. Excitingly, the workshops engaged students in the whole double diamond process: asking them to discover, design, develop, and deliver prototype awards within a two hour timeframe and produced a series of awards to analyze and consider alongside institutional benchmarking and research to build a fuller picture of what drives student engagement in the co-curriculum and when, how, and what sort of advising students seek on experiences for employability outcomes.

Interestingly, the project's starting hypothesis had been that students would like a new award and preliminary discussions had focused on what that might be. However, students in the workshops used creative problem solving to demonstrate that they were satisfied with the current award structure. Those students who had no knowledge of the award designed the components that currently exist. There were also additions: clearer guidelines, ways to connect with each other, a ceremony and certificate, and a pathway toward other awards if they completed this one. Quick wins were the implementation of an annual awards ceremony and a certificate signed by the Deputy Vice Chancellor (Academic). Medium term innovations were a new module in the Learning Management System to display more information for students, provide scaffolded content and clearer learning outcomes, institute a quiz to test knowledge and enable more student-led materials including evidence of engagement through mixed media. Future and longer-term goals are to develop broader partnerships across the University with providers of co-curricular opportunities for students, build an online social media presence, and drive a pipeline through to other engagement awards such as the New Colombo Plan Scholarship that build on the skills, aptitudes, and behaviors the students exhibit in this award. By working directly with students, we have been able to further enhance the existing award in ways that are relevant and responsive to students needs and wants. By learning from them, our assumptions going into the project were challenged and reframed, saving resources and minimizing risk, while engaging students in a high-impact activity that taught them new skills and built new peer connections.

\section{Designing Your Student Experience}

The challenge of addressing personalization at scale has also affected the developmental advising that Melbourne has delivered. Providing individual appointments to students is challenging and there is increasing need to deliver advising services differently and at scale. Understanding more about what students want from advising, whether they want individual or group, when they want it and what it covers is essential 
to designing and delivering a sustainable and relevant service. The developmental advising team led a set of "Design your student experience" HCD workshops with students with the objective of creating a space where students can map out their own journey, consider their academic program, and identify the skills, experiences, and support they need to achieve their goals. With the input and insights of their peers and using creation boards, journey mapping, human scales, prototyping, and other exercises, students produced their own personal plans that encompassed a range of activities they might want to access and participate in across the course of their degree. For many students, this started with a realization that there is more on offer than just their academic timetable so the workshop also served to illuminate opportunities for exploration covering how they might engage themselves academically, emotionally, spiritually, musically, environmentally, and socially. Students discovered study abroad opportunities, great places to eat, still places to sit, activities for sustainability, and other ways to feed their souls while at university. This holistic approach provides a way for students to consider their experience in totality, walk out with an artifact of their own, be creative with others, and put their views forward without judgement. They also have a plan of action but, importantly, with the process of iteration and prototyping, can hopefully see that it is subject to change and can be refined as their journey progresses. The benefits of design thinking were to enable staff to directly take the content and model of an individual advising appointment and test these in a new way of engaging groups of students that uses good developmental and motivational advising techniques but that could be scaled up, yet still creates opportunities for students to connect and personalize their experience.

At the individual level, using HCD to design advising programs and activities has some clear benefits. For advisers used to a holistic person-centered methodology that encourages change and development, reflection, and iteration, as well as action learning, the process of HCD may seem familiar. The methods of design thinking have many similarities to Appreciative Advising and its six stages of disarm, discover, dream, design, deliver, and don't settle (Bloom et al., 2013, pp. 85-8). The emphasis on seeking empathy, defining the problem, ideating or thinking of options, iteration or reflection on the process, building a solution, and testing it out make it a set of methods that can be easily adopted in group settings. In the context of advising and the student experience, this suggests that HCD can provide a sense of methodological legitimacy for institutions to engage more authentically and deeply with their students through co-creation and co-design, especially in considering issues presented by scale and personalization.

\section{CHALLENGES AND LIMITATIONS}

Design thinking is still a new methodology for the University of Melbourne. It is currently forming the basis of new ways of working-across silos in services, between the academic and support areas of the university, between strategy and operations. A new team is being resourced to support the organization and to work across boundaries, to provide access to and application of the student voice, and create empathy and understanding between different groups of staff and stakeholders. This approach is a step change toward embedding design thinking across the organization as part of a broader strategy to firstly, acknowledge and secondly, improve the student experience. These methods are still limited by our ability to have engaged students and especially those students who do not traditionally engage or for whom there are greater barriers to engagement. But once we can access them, as our Supporting Student Performance project demonstrated to us, the lived experience of students and their generosity in sharing insights brings untold value to not just the services we design, but the ways in which we expand our thinking around students and their interactions with us in the twenty-first century. It challenges us to listen in new ways and, for historically conservative institutions, to move away from the centuries of tradition and expertise, to be open to new voices and to recognize that to create a sense of belonging for students, we need to create ways in which their feelings are recognized and valued. This is an approach that has been central to advising practice in other contexts, and must continue to inform the ways we include, value, respect, and teach our students of the future.

\section{CONCLUSION}

High-quality advising and personal tutoring is starting to be acknowledged across the sector as a key to the student experience. Richard Light's foundational work in examining the role and impact of academic and professional staff advising in the US college setting has long held sway about the fundamental role advisors play in shaping the conditions for success, asking "What better way to honor our students, than to ask them about their college experiences? By taking what they say seriously, we can implement ideas that can help students succeed and prosper on our campuses." (Light, 2003). Design thinking challenges individuals to suspend their expert judgement and listen deeply and effectively to student voices, to lived experiences, and to learner insights. This requires leaders and practitioners to be open to ideas and thinking that may test their assumptions and hypotheses, and to reconsider what the student experience of their institution is, and how students want it to be. This is particularly potent for the emerging discipline of academic advising and personal tutoring which positions students at the center of their own educational, personal, and career journeys but which can struggle to find institutional traction in contexts where scale and volume are the primary measures of impact.

Design thinking provides a particularly rich way of engaging students in projects focused on supporting their academic, social, and emotional engagement and provides a way for the institution to take a more holistic approach to understanding and shaping their experience at scale and across the organization. The core principles of design thinking 
provide a critical lens through which to examine the student experience and the resources allocated to it through strategic and operational planning. Many HEIs are now turning their attention to the end-to-end student experience and how services and support functions work to "wrap around" the student's central learning experience. By using tools that elevate and engage with the student experience, institutions can better design advising interactions that are relevant, timely and feel personalized at scale to create conditions for student success in an educational environment that values, listens to and empowers student life, student voice and the student experience.

\section{REFERENCES}

Allen, J., and Nichols, C. (2017). Do you hear me? Student voice, academic success and retention. Stud. Success 8, 123-129. doi: 10.5204/ssj.v8i2.387

Arkoudis, S., Dillinger, M., Baik, C., and Patience, A. (2019). International students' experience in Australian higher education: can we do better? High. Educ. 77, 799-813. doi: 10.1007/s10734-018-0302-x

Arvanitakis, J., and Hornsby, D. (eds.). (2016). “Are universities redundant?," in Universities, the Citizen Scholar and the Future of Higher Education (London: Palgrave Macmillan), 7-20.

Baik, C., Larcombe, W., and Brooker, A. (2019) How universities can enhance student mental wellbeing: the student perspective. High. Educ. Res. Dev. 38, 674-687. doi: 10.1080/07294360.2019.1576596

Bloom, J., Hutson, B., and He, Y. (2013). "Appreciative Advising," in Academic Advising Approaches: Strategies that Teach Students to Make the Most of College, eds J. K. Drayke, P. Jordan, and M. Miller (San Francisco, CA: Jossey-Bass), 83-100.

Bovill, C. (2017). A Framework to explore roles within student-staff partnerships in higher education: which students are partners, when, and in what ways? Int. J. Stud. Partners 1, 1-6. doi: 10.15173/ijsap.v1i1.3062

Bovill, C., Cook-Sather, A., Felten, P., Millard, L., and Moore-Cherry, N. (2016). Addressing potential challenges in co-creating learning and teaching: overcoming resistance, navigating institutional norms and ensuring inclusivity in student-staff partnerships. High. Educ. 71, 195-208. doi: 10.1007/s10734-015-9896-4

British Design Council (2007). Eleven Lessons: Managing Design in Eleven Global Companies. Desk Research Report. Available online at: https://www. designcouncil.org.uk/resources/report/11-lessons-managing-design-globalbrands

British Design Council (2010). Multi-Disciplinary Design Education in the UK: Eight Case Studies. Report and Recommendations from the Multi-Disciplinary Design Network. Available online at: https:/www.designcouncil.org.uk/sites/ default/files/asset/document/multi-disciplinary-design-education.pdf

British Design Council (2015). Design Methods for Developing Services: An Introduction to Service Design and a Selection of Service Design Tools. Guide. Available online at: https://www.designcouncil.org.uk/sites/default/files/ asset/document/DesignCouncil_Design\%20methods\%20for\%20developing $\% 20$ services.pdf

Burdett, J., and Crossman, J. (2011). "Checking the pulse": the international student experience and social engagement across Australian universities: reflecting on AUQA feedback to Cycle 2 reports. J. Int. Educ. Bus. 3, 53-67. doi: $10.1108 / 18363261011106885$

Campbell, S., and Nutt, C. (2008). Academic advising in the new global century: supporting student engagement and learning outcomes achievement. Peer Rev. $10,4-7$.

Carey, P. (2013). Student as co-producer in a marketized higher education system: a case study of students' experience of participation in curriculum design. Innov. Educ. Teach. Int. 50, 250-260. doi: 10.1080/14703297.2013.7 96714

Coates, H. (2014). Students' early departure intentions and the mitigating role of support. Austr. Univ. Rev. 56, 20-29.

\section{ETHICS STATEMENT}

Ethical review and approval was not required for the study on human participants in accordance with the local legislation and institutional requirements. Written informed consent for participation was not required for this study in accordance with the national legislation and the institutional requirements.

\section{AUTHOR CONTRIBUTIONS}

$\mathrm{CM}$ authored the complete work, including drafting, writing, and revision.

Cox, S., and Naylor, R. (2018). Intra-university partnerships improve student success in a first-year success and retention outreach initiative. Stud. Success 9, 51-64. doi: 10.5204/ssj.v9i3.467

Davis, M., and Littlejohn, D. (2017). "The culture of practice: design-based teaching and learning," in Taking Design Thinking to Schools: How the Technology of Design Can Transform Teachers, Learners, and Classrooms, eds S. Goldman and Z. Kabayadondo (New York, NY: Routledge), 20-36.

De Silva, R., and Garnaut, C. (2011). What is the non-academic student experience and why is it important? J. Inst. Res. 16, 69-81.

Drake, J. (2013). "Advising as teaching and the advisor as teacher in theory and in practice," in Academic Advising Approaches: Strategies that Teach Students to Make the Most of College, eds J. K. Drayke, P. Jordan, and M. Miller (San Francisco, CA: Jossey-Bass), 17-32.

Dunne, E. (2016). Design thinking: a framework for student engagement? A personal view. J. Educ. Innov. Partnership Change 2, 1-8.

Goldman, S., and Kabayadondo, Z. (2017). "Taking design thinking to schools: how the technology of design can transform teachers, learners, and classrooms," in Taking Design Thinking to Schools: How the Technology of Design Can Transform Teachers, Learners, and Classrooms, eds S. Goldman and Z. Kabayadondo (New York, NY: Routledge), 3-19.

Karpen, O., Gemser, G., and Calabretta, G. (2017). A multilevel consideration of service design conditions: towards a portfolio of organizational capabilities, interactive practices and individual abilities. J. Serv. Theory Pract. 27, 384-407. doi: 10.1108/JSTP-05-2015-0121

Kift, S. (2015). A decade of transition pedagogy: a quantum leap in conceptualising the first year experience. HERDSA Rev. High. Educ. 2, 51-86.

Kift, S., and Nelson, K. (2005). "Beyond curriculum reform: embedding the transition experience", in Research and Development in Higher Education: Higher Education in a Changing World HERDSA Conference Proceedings 28, eds A. Brew and C. Asmar (The University of Sydney: Sydney, NSW), 225-235.

Kift, S., Nelson, K., and Clarke, J. (2010). Transition pedagogy: a third generation approach to FYE - a case study of policy and practice for the higher education sector. Int. J First Year High. Educ. 1, 1-20. doi: 10.5204/intjfyhe.v1i1.13

Light, R. (2003). Enhancing Student's College Experience With Specific Advising Suggestions. Academic Advising Today. Available online at: https://nacada. ksu.edu/Resources/Academic-Advising-Today/View-Articles/EnhancingStudents-College-Experience- with-Specific-Advising-Suggestions.aspx

Lochtie, D., McIntosh, E., Stork, A., and Walker, B. (2018). Effective Personal Tutoring in Higher Education. St Albans: Critical Publishing.

McInnis, C. (2003). "New realities of the student experience: How should universities respond?," in Paper Presented at European Association for Institutional Research (Limerick).

McIntosh, E. (2017). Working in partnership: the role of peer assisted study sessions in engaging the citizen scholar. Act Learn. High. Educ. 20, 1-16. doi: $10.1177 / 1469787417735608$

Nelson, K., Quinn, C., Marrington, A., and Clarke, J. (2012a). Good practice for enhancing the engagement and success of commencing students. High. Educ. 63, 83-96. doi: 10.1007/s10734-011-9426-y

Nelson, K., Smith, J., and Clarke, J. (2012b). Enhancing the transition of commencing students into university: an institution-wide approach. High. Educ. Res. Dev. 31, 185-199. doi: 10.1080/07294360.2011.556108 
Picton, C., Kahu, E., and Nelson, K. (2018). "Hardworking, determined and happy": first year students' understanding and experience of success. High. Educ. Res. Dev. 37, 1260-1273. doi: 10.1080/07294360.2018.1478803

QILT (2019). 2019 Student Experience Survey: National Report. Available online at: https://www.qilt.edu.au/docs/default-source/default-document-library/ 2018-ses-national-report.pdf?sfvrsn $=$ d0f7ec3c $\_0$

Roberts, P., and Dunworth, K. (2012). Staff and student perceptions of support services for international students in higher education: a case study. J. High. Educ. Policy Manag. 34, 517-528. doi: 10.1080/1360080X.2012.716000

Roth, B. (2017). "Foreword," in Taking Design Thinking to Schools: How the Technology of Design Can Transform Teachers, Learners, and Classrooms, eds S. Goldman and Z. Kabayadondo (New York, NY: Routledge), xvi-xviii.

Stickdorn, M., Hormess, M., Lawrence, A., and Schneider, J. (2018). This Is Service Design Doing: Applying Service Design Thinking in the Real World. O'Reilly Media, Incorporated; ProQuest Ebook Central. Available online at: https:// ebookcentral.proquest.com/lib/rmit/detail.action?docID $=5219777$

Thomas, L. (2012). Building Student Engagement and Belonging in Higher Education at a Time of Change: Final Report from the What Works? Student Retention and Success Programme. London: Paul Hamlyn Foundation.

University of Melbourne (2017). Improving the International Commencing Student Onboarding Experience. 2018 Programme Report, (Melbourne, VIC).

University of Melbourne (2018). Supporting Student Performance: How Might We Support Student Success at the University of Melbourne? Report, (Melbourne, VIC)

Varney, J. (2013). "Proactive Advising" in Academic Advising Approaches: Strategies that Teach Students to Make the Most of College, eds J. K. Drayke, P. Jordan, and M. Miller (San Francisco, CA: Jossey-Bass), 137-154.
Varnham, S. (2018). Student Engagement in University Decision-Making and Governance: Towards a More Systemically Inclusive Student Voice 20152016. Final Report 2018. Department of Education and Training. Available online at: https://altf.org/wp-content/uploads/2017/06/SP14-4595_Varnham_ FinalReport_2018.pdf

Wilcox, E. (2016). An End to Checklist Thinking: Learning-Centered Advising in Practice. NACADA Clearinghouse of Academic Advising Resources. Available online at: http://nacada.ksu.edu/tabid/3318/articleType/ArticleView/articleId/ 6101/article.aspx

Wood, D., Gray-Gantner, G., and Bailey, R. (2016). Pre-commencement interviews to support transition and retention of first year undergraduate students. Student Success. 7:2, 21-31. doi: 10.5204/ssj.v7i2.338

Young-Jones, A., Burt, T., Dixon, S., and Hawthorne, M. (2013). Academic advising: does it really impact student success? Quality Assurance in Education. 21:1, 7-19. doi: 10.1108/096848813112 93034

Conflict of Interest: The author declares that the research was conducted in the absence of any commercial or financial relationships that could be construed as a potential conflict of interest.

Copyright $\odot 2020$ Mann. This is an open-access article distributed under the terms of the Creative Commons Attribution License (CC BY). The use, distribution or reproduction in other forums is permitted, provided the original author $(s)$ and the copyright owner(s) are credited and that the original publication in this journal is cited, in accordance with accepted academic practice. No use, distribution or reproduction is permitted which does not comply with these terms. 